\title{
SUGGESTING A SIMPLE DESIGN METHOD FOR COLD RECYCLED ASPHALT MIXES WITH ASPHALT EMULSION
}

\author{
Bahador BAZRAFSHAN MOGHADAM, Hamid FARHAD MOLLASHAHI \\ Department of Civil engineering, Faculty of Engineering, University of Torbat Heydarieh, \\ postal code: 9516168595, Torbat Heydarieh, Iran
}

Received 11 Dec 2016; accepted 06 Jun 2017

\begin{abstract}
Although there are typical and well-known standard methods for designing hot mix asphalt in the world, there is no unique design method for cold recycled asphalt mixes. The current methods are mainly local or even dependent on technology owners due to the diversity of materials and qualitative control limitations. Currently, most of the design methods are based on 4 inch mold. The major problem of these methods is that in the mix design, the effect of aggregates larger than $25 \mathrm{~mm}$ is neglected, while this size of aggregates is used in the recycling projects. Therefore, there is a significant difference between in-situ and laboratory mix behaviors. So, 6-inch mold is used. In this study, a simple mix design has been obtained for reclaimed asphalt pavements (RAP) considering the different amount of emulsified asphalt, Portland cement, three gradations, moisture contents, temperatures, and curing times. For this reason, 315 samples were prepared. The results show that the mixes with aggregates larger than $25 \mathrm{~mm}$ have a significant difference with $25 \mathrm{~mm}$ and smaller aggregates sizes in terms of mechanical properties and moisture susceptibility. Therefore, 6-inch molds should be used for RAP materials that are larger than $25 \mathrm{~mm}$ in the mix design.
\end{abstract}

Keywords: cold recycling, mix design, reclaimed asphalt pavement (RAP), emulsified asphalt, curing condition, performance tests.

\section{Introduction}

Asphalt pavements recycling, using cold and hot methods, is one of the most effective rehabilitation and reclamation methods (Ma et al. 2016). The recycling process refers to reusing the existing pavement materials which have reached the end of their service life. Among the available technics, cold in-place recycling (CIR) is an option with environmental and economic benefits. It can perform the process of modification and reuse of top layers aggregates easily through one passage of advanced machinery without causing any damage to its subgrade. Nowadays, there are various codes to design of cold recycled mixes in different countries based on experience and research. However, there is no unique standard or approved method for mix design, structural design, laboratory evaluation method and quality control characteristics for CIR (Apeagyei, Diefender 2013, Asphalt Recycling and Reclaiming Association 2001, 2004; Bessa et al. 2016; Cox, Howard 2015; Du 2015; Kavussi, Modarres 2010; Kim 2007; Lee 2003; Martinez-Echevarria et al. 2012; Tebaldi et al. 2014). Different institutions includ- ing the Joint Committee of AASHTO ${ }^{1}$-AGC ${ }^{2}$-ARTBA ${ }^{3}$, $\mathrm{AI}^{4}$ and $\mathrm{ARRA}^{5}$ have presented general methods for designing CIR mixes based on hot mix asphalt (HMA) design methods. Most of the recent mix design methods are based on a series of parameters and characteristics (Marshal resistance, uniaxial compressive strength, indirect tensile strength (ITS), resilient modulus, etc.) along with estimating of their limits and values (Asphalt Recycling and Reclaiming Association 2004; Kavussi, Modarres 2010; Kim 2007; Suleiman 2002). And the optimum value of each constituent and mix design are specified.

Recently, in the majority of cases, 4-inch molds are used in recycled pavements mix design (whether in recycling with foamed asphalt or with emulsified asphalt). The mix design is based on Superpave or Marshal tests,

\footnotetext{
${ }^{1}$ American Association of State Highway and Transportation Officials

${ }^{2}$ Associated General Contractors of America

${ }^{3}$ American Road and Transportation Builders Association

${ }^{4}$ Asphalt Institute

${ }^{5}$ Asphalt Recycling and Reclaiming Association
} 
bulk and theoretical maximum specific gravity, air voids, and resistance to fatigue and rutting. The first step of these methods is the assessment of pavement condition and evaluation of recycled aggregates (including gradation, the amount of asphalt of RAP materials, etc.), and then laboratory samples are prepared to estimate the optimum amount of additives (water and emulsified asphalt) (Cox, Howard 2015).

Due to the usage of 4-inch molds, grains larger than $25 \mathrm{~mm}$ are separated from aggregates. Therefore, mix design is changed into a mix with different gradation and thus with different characteristics from those that constructed in the field. Considering the significance of cold recycling as an economical modification technic for old pavements, use of a design method based on gradation close to field conditions is necessary. In addition, those methods not only have shortcoming in aggregate gradation but also the calculation of other properties such as specific gravity is based on old and common tests which are not able to well reflect the behavior and properties of the recycled mixes. As a result, this study deals with the introduction of a simple mix design method based on performance tests. It also evaluates the effect of gradation on the properties of these mixes.

The objective of this research is to develop a simple mix design for cold in-place recycling with emulsified asphalt through reviewing former studies. To accomplish this objective, the following tasks are performed:

- Review and comparison of previous research on mix design methods;

- Suggesting a simple mix design method for cold recycled mixes based on performance tests;

- Investigation of the effect of gradation and maximum size of RAP materials on resistance properties of cold recycled mixes;

- Investigation and comparison of the use of 4 and 6-inch molds in the mix design.

\section{Literature review}

Currently, there is no unique and universal mix design method for cold in-place recycling. Although these design methods are similar in their steps, Lots of procedures are made and modified by different agencies, countries and factories based on past experiences and laboratory tests (Asphalt Recycling and Reclaiming Association 2004; Cox, Howard 2015; Bessa et al. 2016).

The most important methods that exist are as follow: AASHTO, California, Chevron, US Army Corps of Engineers, Illinois, Mississippi, Kansas, Iowa, Montana, Oregon, Pennsylvania, New Mexico, Nevada, Texas, Virginia, New York, Spain, Purdue and AI (AASHTO 1998; Cox, Howard 2015).

In most methods, the primary steps of designing (i.e. collection of RAP, aggregate gradation, RAP characteristics, ...) is similar so the focus of this research is on the parameters that make the methods different. The main parameters are presented as follows.

\subsection{Recycling agent and chemical additives}

Based on previous research, it has been recognized that emulsified asphalt has the greatest usage in pavement recycling as the primary binder in multiple component binder (MCB) systems (Cox, Howard 2015). And in different types of emulsified asphalt, medium setting (MS) emulsions (commonly high float anionic type) have the greatest application in the cold in-place recycling process (Lee, Kim 2010; Kim 2007).

In MCB systems, in addition to emulsified asphalt, the usage of Portland cement, hydrated lime and fly ash are common (Cox, Howard 2015). Use of chemical additive not only decrease the amount of asphalt but also improves the mechanical properties (such as indirect tensile strength, ...) of the mix (Du 2015; Kavussi, Modarres 2010; Niazi, Jalili 2009). Many researches have proved that portland cement has greater effects on mix properties than other chemical additives and it is generally added $1 \%$ to $3 \%$ by mass to the mix (Bessa et al. 2016; Bocci et al. 2014; Cox, Howard 2015; Du 2015; Iwański, ChomiczKowalska 2016; Miro et al. 2000; Niazi, Jalili 2009).

\subsection{Preparation of laboratory samples}

Comparing the previous studies have shown that application of Superpave gyratory compactor (SGC) in designing and preparing of laboratory samples is more effective and useful than using other compactors (Cox, Howard 2015; Cross 2003). However, in many methods and countries, considering technological and financial limitations, Marshal hammer is used instead of the SGC (Bessa et al. 2014; California Department of Transportation 2005; Cross et al. 2010; Du 2015; Kavussi, Modarres 2010; Virginia Department of Transportation 2014). However, it should be noted that in many of existing design methods, both 50 blows of marshall compaction (AASHTO 1998) and 75 blows of Marshall compaction is used to compact laboratory samples (Apeagyei, Diefender 2013; Bessa et al. 2014; California Department of Transportation 2005; Cross et al. 2010; Du 2015; Iwański, Chomicz-Kowalska 2016; Lee et al. 2002; Virginia Department of Transportation 2014). In sample preparation, both 4 and 6 inch molds have been used, but in 6-inch molds to eliminate pore water pressure, voided molds are used.

\subsection{Determination of the optimum amount of water and emulsified asphalt}

Currently, in new mix design methods, total liquid content (TLC) is used in the design of cold recycled mixes (Bou Jove et al. 2004; Cox, Howard 2013; Fiser, Varaus 2004; Miro et al. 2004). The procedure is the same as proctor compaction test and optimum amount of TLC is selected based on maximum bulk specific gravity test. In this method, according to same role of water and emulsified asphalt on the level of compaction, all of the samples were prepared by water and compacted with Marshall hammer. Then, based on specified parameters, the 
optimum amount of water and emulsified asphalt is selected. Several parameters are involved in selecting of optimum cold recycled mixes in new methods. And the most common of them are as follows: bulk specific gravity, rutting resistance, raveling, fatigue, moisture damage and thermal cracks (Cox, Howard 2015). The mentioned tests are the best to reflect the behavior and performance characteristics of the mix. But the shortage of the advanced equipment in laboratories made it impossible to perform all of them. So, nowadays each design methods use their own procedures and testing programs. But the most popular, simple and comprehensive test that reflects many characteristics of the cold recycling mixes is indirect tensile strength test. So, many researchers had taken the advantage of this test (Apeagyei, Diefender 2013; Cross 1999; Dudley et al. 1987; Kavussi, Modarres 2010; Marcandali da Silva et al. 2013; Kim et al. 2011; Niazi, Jalili 2009; Yan et al. 2009). Another parameter that can be achieved by the ITS test is tensile strength ratio (TSR) and it reflects the moisture susceptibility of the recycled mixes. There are different opinion about TSR value and it ranges between 0.5 and 0.75 in different design methods. However, the common and rational ratio in different codes is the minimum of 0.7 (California 2005; Cross et al. 2010; Illinois Department of Transportation 2012; Iowa Department of Transportation 2008; Kansas Department of Transportation 2014; Lane, Kazmievowski 2005; Montana Department of Transportation 2015; Texas Department of Transportation 2004; Virginia Department of Transportation 2014).

\subsection{Performance tests}

The past research in evaluation of asphalt mixes showed that the total area under the stress-strain curve in ITS test up to the sample's failure has a good relationship with the resistance of the mixes to fatigue cracking (Christensen, Bonaquist 2002; Cox, Howard 2015; Koh, Roque 2010; Kim, Wen 2002; Roque et al. 2004; Transportation Research Board 2004; Zhang et al. 2001).

Currently, there are many standardized laboratory tests to predict pavement layers rutting potentials. Some of the most common tests used include: Asphalt Mixture Performance Tester (AMPT), Hamburg Wheel Tracking Tester (HLWT), Asphalt Pavement Analyzer (APA), PURWheel (PW), French Rutting Tester (FRT), Static Creep Test (Cox, Howard 2015; Kandhal, Cooley 2003). Although the loaded wheel tester (LWT) type of devices are the common tests and providing a more realistic evaluation of the mix, they are so expensive. In recent decades, static creep test has been used as a basic test for evaluation of rutting resistance in hot mix asphalt. Various researchers have proposed different methods for performing this test.

\section{Methodology and laboratory experiments}

According to different design methods of cold recycled mixes, the following steps were done.

\subsection{Collection of RAP materials}

In this research, the required RAP materials were collected from eastbound of the Tehran's Azadegan highway. The asphalt pavement has been crushed by a milling machine with a width of $1 \mathrm{~m}$, with the cutting depth of $10 \mathrm{~cm}$.

\subsection{Determination of RAP materials gradation}

After collecting and transporting the RAP materials to the laboratory, sampling of RAP materials was done according to the ASTM D75M (2014).

\subsection{Determination of RAP materials Characteristics}

The properties studied in this section include determination of the percentage of asphalt according to the ASTM D6307 (2016) and gradation of extracted RAP materials according to the ASTM C136 (2014).

\subsection{Proper Selection of aggregate gradation}

Based on previous studies, the need for further research in this area seem to be required (Frigio et al. 2015; Vislavičius, Sivilevičius 2013). So, three different dense gradations (with the maximum aggregate size of 19, 25 and $37.5 \mathrm{~mm}$ ) have been examined based on a report of federal highway administration (FHWA). The resulting cumulative gradations are shown in Table 1.

\subsection{Selection of the suitable type of emulsified asphalt and chemical additive}

In this paper, due to lack of access to high float anionic medium setting emulsion, medium setting cationic emulsion has been used and 2\% Portland cement (that suggested in a research by Niazi and Jalili (2009)) is used to improve the initial mechanical properties of the recycled mix.

\subsection{Performing classic and Superpave tests on asphalt emulsion residues}

After determination of the type of asphalt emulsion, the asphalt residue was separated according to ASTM D244 (2009) instruction. And then classic (penetration, softening point, ductility) and Superpave (resistance to fatigue using Dynamic Shear Rheometer (DSR) and resistance to thermal cracks using Bending Beam Rheometer (BBR)) tests according to the related ASTM instructions were performed to determine its performance grading (PG).

\subsection{Preparation of laboratory samples}

In this research Marshall hammer has been used as a simple and more accessible compaction methods. And two compaction levels (50 and 75 blows) and comparison of the results from specific gravity and performance properties of the samples has been done. 4-inch molds have been used for the maximum aggregate size of 19 and $25 \mathrm{~mm}$ and 6-inch molds have been used for the maximum aggregate size of $37.5 \mathrm{~mm}$. Due to eliminate the 
Table 1. Detailed proportions of three RAP gradations

\begin{tabular}{|c|c|c|c|c|c|c|c|}
\hline \multirow{3}{*}{$\begin{array}{l}\text { sieve } \\
\text { size } \\
(\mathrm{mm})\end{array}$} & \multirow{3}{*}{$\begin{array}{l}\text { percent } \\
\text { passing } \\
\text { of } \\
\text { existing } \\
\text { RAP }\end{array}$} & \multicolumn{6}{|c|}{ maximum aggregate size of } \\
\hline & & \multicolumn{2}{|l|}{$19 \mathrm{~mm}$} & \multicolumn{2}{|l|}{$25 \mathrm{~mm}$} & \multicolumn{2}{|l|}{$37.5 \mathrm{~mm}$} \\
\hline & & $\begin{array}{l}\text { percent passing } \\
\text { of RAP materials by } \\
\text { removing aggregates } \\
\text { larger than } 19 \mathrm{~mm}\end{array}$ & $\begin{array}{l}\text { selected } \\
\text { gradation }\end{array}$ & $\begin{array}{l}\text { percent passing } \\
\text { of RAP materials by } \\
\text { removing aggregates } \\
\text { larger than } 25 \mathrm{~mm}\end{array}$ & $\begin{array}{l}\text { selected } \\
\text { gradation }\end{array}$ & $\begin{array}{l}\text { percent passing } \\
\text { of RAP materials by } \\
\text { removing aggregates } \\
\text { larger than } 37.5 \mathrm{~mm}\end{array}$ & $\begin{array}{l}\text { selected } \\
\text { gradation }\end{array}$ \\
\hline 50 & 100.0 & 100.0 & 100.0 & 100.0 & 100.0 & 100.0 & 100.0 \\
\hline 37.5 & 99.5 & 100.0 & 100.0 & 100.0 & 100.0 & 100.0 & 100.0 \\
\hline 25 & 97.2 & 100.0 & 100.0 & 100.0 & 100.0 & 97.6 & 96.0 \\
\hline 19 & 91.5 & 100.0 & 100.0 & 94.1 & 94.0 & 91.9 & 90.0 \\
\hline 12.5 & 82.4 & 90.0 & 90.0 & 84.8 & 85.0 & 82.8 & 79.0 \\
\hline 9.5 & 74.6 & 81.0 & 81.0 & 76.3 & 76.0 & 74.5 & 70.0 \\
\hline 4.75 & 50.7 & 55.4 & 55.4 & 52.1 & 52.0 & 50.9 & 47.0 \\
\hline 2.36 & 28.4 & 31.1 & 38.0 & 29.2 & 33.0 & 28.6 & 29.0 \\
\hline 1.18 & 14.4 & 15.7 & 25.0 & 14.8 & 22.0 & 14.5 & 19.0 \\
\hline 0.6 & 6.5 & 7.1 & 17.0 & 6.7 & 16.0 & 6.6 & 13.0 \\
\hline 0.3 & 3.8 & 4.2 & 12.0 & 3.9 & 11.0 & 3.8 & 9.0 \\
\hline 0.15 & 1.2 & 1.3 & 8.0 & 1.2 & 7.0 & 1.2 & 6.0 \\
\hline 0.075 & 0.4 & 0.5 & 5.0 & 0.4 & 4.0 & 0.4 & 3.0 \\
\hline Pan & 0 & 0 & 0 & 0 & 0 & 0 & 0 \\
\hline \multicolumn{2}{|c|}{$\begin{array}{l}\text { *percent of } \\
\text { added } \\
\text { virgin aggregates }\end{array}$} & \multicolumn{2}{|l|}{9.8} & \multicolumn{2}{|l|}{9.3} & \multicolumn{2}{|l|}{10.9} \\
\hline \multicolumn{8}{|c|}{$\begin{array}{l}\text { * It should be noted that: } \\
1 \text { - New aggregates (nearly } 10 \%) \text { was added to the RAP to satisfy the gradation requirement, due to the lack of fine aggregates } \\
\text { in the RAP materials. } \\
2 \text { - For the studied gradations }(19,25,37.5 \mathrm{~mm}) \text {, nearly the same amount of new aggregates and parallel aggregate gradation } \\
\text { curves is chosen. So, better comparison and evaluation of mixes properties is expected. }\end{array}$} \\
\hline
\end{tabular}

pore water pressure in 6-inch molds, voided molds similar to those constructed by Pine Co., was used.

According to the former studies, in this research the blending process consists of mixing the RAP materials with chemical additive (Portland cement) at the specified amount. Then mixing with water for 60 seconds and at last mixing with emulsified asphalt for another $60 \mathrm{sec}-$ onds.

\subsection{Determination of the required total liquid content (TLC)}

In this research, this parameter has been used to determine the optimum amount of water and emulsified asphalt. The procedure is the same as proctor compaction test with the exception that the Marshall hammer is used for compaction.

\subsection{Determination of the optimum amount of water and emulsified asphalt based on selected tests}

According to different new design methods and the existing equipment, in this research, bulk and theoretical maximum specific gravity, ITS in dry and saturated conditions have been used in design of recycled mixes. Calculating the optimum amount of water and emulsified asphalt of the recycled mix has been done based on the following tests:

1. Bulk Specific Gravity according to AASHTO T331 with vacuum sealed specimens.

2. ITS of the samples according to AASHTO T283 with partial curing (to simulate the mix after compaction in field).

3. ITS of the samples according to AASHTO T283 with final curing in dry and saturated conditions (to simulate the long-term strength of the mix) and calculation of tensile strength ratio (TSR). Note:

In ITS test, two loading strips was mounted on Marshall stability load frame to calculate the tensile strength of cylindrical specimens in vertical diametric plane. Then, the indirect tensile strength of the specimens calculated according to Eqn (1):

$$
I T S=\frac{2000 P_{\max }}{\pi t d},
$$

where: ITS - indirect tensile strength, $\mathrm{kPa} ; P_{\max }-$ peak load, $\mathrm{N} ; d$-diameter of the specimen, $\mathrm{mm} ; t$ - thickness of the specimen, mm (Kavussi, Modarres 2010). 


\subsection{Investigation of laboratory mixes behavior in terms of fatigue resistance}

With regard to the past research, the ITS test and the plot of stress-strain curve of its data is used to examine the fatigue behavior in recycled mixes with different gradation.

\subsection{Evaluation and comparison of rutting resistance}

Based on previous studies, static creep test is selected for evaluation of rutting resistance. Since the recycled layer is commonly used as a base in pavement structure, thus the amount of stress exerted to this layer is lower than to the top layers. Thus, in order to investigate the rutting behavior of recycled mixes with different gradations and considering the lower quality of these mixes (compared with hot mix asphalt), DD-185 instruction by British Standard Institute has been used.

\section{Results and discussions}

\subsection{Determination of required TLC}

By determination of grading limits, laboratory samples were prepared and the amount of required liquid agent through different compaction energies has been done. According to same role of water and emulsified asphalt on the level of compaction, all of samples were prepared by water and compacted with Marshall hammer. The summary of the results is provided in Table 2 .

Data obtained from the optimum liquid content determination test shows that:

1. The optimum amount of liquid agent of the samples have a significant difference in different compaction energies (50 and 75 compaction blows) in the studied gradations by nearly $9 \%$.

2. Investigating the amount of air voids reveal that the selected gradations of 19 and $25 \mathrm{~mm}$ have been suitable, meeting the minimum requirements for preparation of recycled base layer (around 14\%), while the $37.5 \mathrm{~mm}$ gradation has a low specific gravity and a high amount of air voids by nearly $17 \%$.

3 . Based on the results obtained from this section along with the significance of the bulk specific gravity and the amount of air voids in the performance of asphalt mixes, the use of 75 compaction blows is chosen for the rest of the work.

\subsection{Determination of the optimum amount of emulsi- fied asphalt and water}

By determining the optimum liquid content in each gradation, the optimum amount of water and emulsified asphalt should be determined. At this step, by keeping the TLC constant, the amount of water and emulsified asphalt is changed, and samples are prepared with different amount of liquid agent. The tests included ITS in partial and final curing along with moisture susceptibility test.

\subsubsection{ITS test in partial curing}

Considering the passage of traffic stream over the recycled pavement, after a short period of time of its construction, the cohesive strength of cold recycled mixes is known as one of its important characteristics (Kim et al. 2011; Sebaaly et al. 2004). So, ITS test in the short term stage has been conducted to examine the cohesion values.

In this method, for partial curing, at first, the samples were subject to $60^{\circ} \mathrm{C}$ in an oven for 6 hours. Then, they are kept for another 12 hours at the room temperature. Finally, they were removed from the molds and then tested (AASHTO 1998; Lee et al. 2002). The test results are shown in Table 3.

Analysis of the data in Table 3, reveals that:

1. In 19 and $25 \mathrm{~mm}$ gradations, in initial mixing water of $2 \%$, the maximum tensile strength has been obtained. Therefore, it can be stated that the mix with $2 \%$ of initial water will probably have the best strength to raveling under traffic stream.

2. In $37.5 \mathrm{~mm}$ gradation, no certain trend can be observed among the tensile strength and amount of water, and a great discrepancy is seen between the parameters. This can be due to the low quality and Inhomogeneity of the samples in this group, which is itself dependent on large gradation and improper physical characteristics of the mix (e.g. low bulk specific gravity, high air voids, etc.) as it can be seen in variation analysis data shown in Table 3.

Table 2. The results of optimum liquid content for the studied gradations

\begin{tabular}{|c|c|c|c|c|c|c|c|c|c|}
\hline \multirow{3}{*}{$\begin{array}{c}\text { Number of } \\
\text { compaction } \\
\text { blows }\end{array}$} & \multicolumn{9}{|c|}{ maximum aggregate size of } \\
\hline & \multicolumn{3}{|c|}{$19 \mathrm{~mm}$} & \multicolumn{3}{|c|}{$25 \mathrm{~mm}$} & \multicolumn{3}{|c|}{$37.5 \mathrm{~mm} *$} \\
\hline & $\begin{array}{c}\text { Bulk } \\
\text { specific } \\
\text { gravity } \\
\left(\mathrm{gr} / \mathrm{cm}^{\wedge} 3\right)\end{array}$ & $\begin{array}{l}\text { Optimum } \\
\text { liquid } \\
(\%)\end{array}$ & $\begin{array}{c}\text { Average } \\
\text { air voids } \\
(\%)\end{array}$ & $\begin{array}{c}\text { Bulk } \\
\text { specific } \\
\text { gravity } \\
\left(\mathrm{gr} / \mathrm{cm}^{\wedge} 3\right)\end{array}$ & $\begin{array}{l}\text { Optimum } \\
\text { liquid } \\
(\%)\end{array}$ & $\begin{array}{c}\text { Average } \\
\text { air voids } \\
(\%)\end{array}$ & $\begin{array}{c}\text { Bulk } \\
\text { specific } \\
\text { gravity } \\
\left(\mathrm{gr} / \mathrm{cm}^{\wedge} 3\right)\end{array}$ & $\begin{array}{l}\text { Optimum } \\
\text { liquid } \\
(\%)\end{array}$ & $\begin{array}{c}\text { Average } \\
\text { air voids } \\
(\%)\end{array}$ \\
\hline 50 & 2.054 & 5.8 & 15.8 & 2.024 & 5.5 & 15.9 & \multicolumn{3}{|c|}{$* *$} \\
\hline 75 & 2.089 & 5.3 & 13.6 & 2.073 & 5 & 14 & 1.983 & 4.3 & 17.3 \\
\hline \multicolumn{10}{|c|}{$\begin{array}{l}\text { Notes: } \\
* \text { The number of compaction blows in the } 6 \text {-inch molds has been obtained according to the same compaction energy of the mix } \\
\text { in relation with the } 4 \text {-inch molds. } \\
\text { ** due to the incompetency of } 50 \text { blows compaction method, in the } 37.5 \mathrm{~mm} \text { gradation the equivalent compaction of } 50 \text { blows, } \\
\text { was not conducted. }\end{array}$} \\
\hline
\end{tabular}


Table 3. Indirect tensile strength of 19, 25 and $37.5 \mathrm{~mm}$ gradations in partial curing

\begin{tabular}{|c|c|c|c|c|c|c|c|c|c|c|c|}
\hline \multicolumn{4}{|c|}{$\begin{array}{c}19 \mathrm{~mm} \\
\mathrm{TLC}=5.3 \%\end{array}$} & \multicolumn{4}{|c|}{$\begin{array}{c}25 \mathrm{~mm} \\
\mathrm{TLC}=5 \%\end{array}$} & \multicolumn{4}{|c|}{$\begin{array}{c}37.5 \mathrm{~mm} \\
\mathrm{TLC}=4.3 \%\end{array}$} \\
\hline \multicolumn{8}{|c|}{ 4-inch mold } & \multicolumn{4}{|c|}{ 6-inch mold } \\
\hline Sample & $\begin{array}{c}\text { Initial } \\
\text { mixing } \\
\text { water } \\
(\%)\end{array}$ & $\begin{array}{l}\text { emulsified } \\
\text { asphalt } \\
(\%)\end{array}$ & $\begin{array}{c}\text { Average } \\
\text { ITS } \\
(\mathrm{kPa})\end{array}$ & Sample & $\begin{array}{c}\text { Initial } \\
\text { mixing } \\
\text { water } \\
(\%)\end{array}$ & $\begin{array}{l}\text { emulsified } \\
\text { asphalt } \\
(\%)\end{array}$ & $\begin{array}{c}\text { Average } \\
\text { ITS } \\
(\mathrm{kPa})\end{array}$ & Sample & $\begin{array}{l}\text { Initial mix- } \\
\text { ing } \\
\text { water } \\
(\%)\end{array}$ & $\begin{array}{l}\text { emulsified } \\
\text { asphalt } \\
(\%)\end{array}$ & $\begin{array}{c}\text { Average } \\
\text { ITS } \\
(\mathrm{kPa})\end{array}$ \\
\hline 1 & 1.5 & 3.8 & \multirow{3}{*}{212.5} & 1 & 1.5 & 3.5 & \multirow{3}{*}{177.6} & 1 & 1.5 & 2.8 & \multirow{3}{*}{108.5} \\
\hline 2 & 1.5 & 3.8 & & 2 & 1.5 & 3.5 & & 2 & 1.5 & 2.8 & \\
\hline 3 & 1.5 & 3.8 & & 3 & 1.5 & 3.5 & & 3 & 1.5 & 2.8 & \\
\hline 4 & 2 & 3.3 & \multirow{3}{*}{222.4} & 4 & 2 & 3 & \multirow{3}{*}{213.7} & 4 & 2 & 2.3 & \multirow{3}{*}{89.1} \\
\hline 5 & 2 & 3.3 & & 5 & 2 & 3 & & 5 & 2 & 2.3 & \\
\hline 6 & 2 & 3.3 & & 6 & 2 & 3 & & 6 & 2 & 2.3 & \\
\hline 7 & 2.5 & 2.8 & \multirow{3}{*}{211.4} & 7 & 2.5 & 2.5 & \multirow{3}{*}{174.4} & 7 & 2.5 & 1.8 & \multirow{3}{*}{101.5} \\
\hline 8 & 2.5 & 2.8 & & 8 & 2.5 & 2.5 & & 8 & 2.5 & 1.8 & \\
\hline 9 & 2.5 & 2.8 & & 9 & 2.5 & 2.5 & & 9 & 2.5 & 1.8 & \\
\hline 10 & 3 & 2.3 & \multirow{3}{*}{210.7} & 10 & 3 & 2 & \multirow{3}{*}{182.4} & \multirow{6}{*}{\multicolumn{4}{|c|}{$\begin{array}{l}\text { Note: } \\
\text { for this gradation, because of low amount of } \\
\text { TLC, the initial mixing water above } 2.5 \% \text { is } \\
\text { neglected to avoid poor mix. }\end{array}$}} \\
\hline 11 & 3 & 2.3 & & 11 & 3 & 2 & & & & & \\
\hline 12 & 3 & 2.3 & & 12 & 3 & 2 & & & & & \\
\hline 13 & 3.5 & 1.8 & \multirow{3}{*}{208.2} & 13 & 3.5 & 1.5 & \multirow{3}{*}{174.5} & & & & \\
\hline 14 & 3.5 & 1.8 & & 14 & 3.5 & 1.5 & & & & & \\
\hline 15 & 3.5 & 1.8 & & 15 & 3.5 & 1.5 & & & & & \\
\hline
\end{tabular}

Note:

In order to investigate the variation of results, variation analysis was done at each testing condition:

- In $19 \mathrm{~mm}$ gradation, in all cases the coefficient of variation (CV) were in the range of 1.2 to $9.7 \%$.

- In $25 \mathrm{~mm}$ gradation, in all cases the coefficient of variation (CV) were in the range of 1.2 to $10.9 \%$.

- In $37.5 \mathrm{~mm}$ gradation, in all cases the coefficient of variation (CV) were in the range of 23.6 to $34.8 \%$.

3. Although in hot mix asphalt, the higher the amount of asphalt, the greater the extent of cohesion, in cold recycled mixes, this phenomenon does not occur. Because the emulsified asphalt required a minimum moisture level for better dispersion and distribution in the recycled mix. In conclusion, the maximum level of tensile strength does not occur at the maximum amount of emulsion. Western US Research Institute also proved that the amount of the optimum emulsified asphalt, as well as the mechanical properties of the mix, are a function of aggregates moisture and the type of the emulsified asphalt. Therefore, it is wrong to use a constant level of water in preparation of the mix and determination of the optimum emulsion amount as it can be seen in Table 3 .

$4.19 \mathrm{~mm}$ gradation has a greater strength compared with the $25 \mathrm{~mm}$ gradation. It can be due to greater homogeneity and compaction level and the lower air voids in these samples. So, if it designed well, it can be used as binder course in pavement structure.

\subsubsection{Moisture susceptibility test after final curing}

To examine the long-term behavior of recycled mixes along with their resistance to moisture damages, ITS test in dry and saturated conditions has been used. In cold recycled mixes, one of the most important parameters in determination of the optimum amount of recycling agents is the extent of moisture susceptibility of the mixes. In mix design, the importance and the role of extent of resistance in saturated condition is greater than that of in dry condition. This is due to the fact that the majority of mixes prepared in laboratory, meet the minimum level of dry resistance, though this is not a reason for meeting the TSR limits. In this stage, the ITS test has been done on the specimens at two curing conditions:

- 3 days at $40{ }^{\circ} \mathrm{C}$ ( $\mathrm{Fu}$ et al. 2009; Wirtgen 2006) and

- 2 days at $60^{\circ} \mathrm{C}$ (Iowa Department of Transportation 2008; Wegman, Sabouri 2016),

where moisture susceptibility test has been performed according to AASHTO T283 (2014) instruction. The summary of the test results for optimum mixes is provided in Table 4.

According to the data in Table 4, the following results are obtained:

1. Selection of the optimum mix depends on curing conditions, so different types of curing can cause different optimum mix. It is at the same result of Kim's et al. (2011) article. 
Table 4. The summary of indirect tensile strength in 19, 25 and $37.5 \mathrm{~mm}$ gradations for optimum mixes in two curing conditions

\begin{tabular}{|c|c|c|c|c|c|c|c|c|c|c|}
\hline \multirow[b]{3}{*}{$\begin{array}{l}\text { Gradation } \\
(\mathrm{mm})\end{array}$} & \multicolumn{10}{|c|}{ sample curing } \\
\hline & \multicolumn{5}{|c|}{3 days at $40^{\circ} \mathrm{C}$} & \multicolumn{5}{|c|}{2 days at $60^{\circ} \mathrm{C}$} \\
\hline & $\begin{array}{c}\text { Initial } \\
\text { mixing } \\
\text { water } \\
(\%)\end{array}$ & $\begin{array}{l}\text { Emulsified } \\
\text { asphalt } \\
(\%)\end{array}$ & $\begin{array}{c}\text { ITS } \\
\text { in dry } \\
\text { condition } \\
(\mathrm{kPa})\end{array}$ & $\begin{array}{c}\text { ITS } \\
\text { in saturated } \\
\text { condition } \\
(\mathrm{kPa})\end{array}$ & TSR & $\begin{array}{c}\text { Initial } \\
\text { mixing } \\
\text { water } \\
(\%)\end{array}$ & $\begin{array}{l}\text { Emulsified } \\
\text { asphalt } \\
(\%)\end{array}$ & $\begin{array}{c}\text { ITS } \\
\text { in dry } \\
\text { condition } \\
(\mathrm{kPa})\end{array}$ & $\begin{array}{c}\text { ITS } \\
\text { in saturated } \\
\text { condition } \\
(\mathrm{kPa})\end{array}$ & TSR \\
\hline 19 & 2.0 & 3.3 & 347.9 & 239.8 & 0.69 & 2.5 & 2.8 & 350.7 & 304.7 & 0.87 \\
\hline 25 & 2.5 & 2.5 & 332.8 & 263.7 & 0.79 & 2 & 3 & 438.7 & 332.7 & 0.76 \\
\hline 37.5 & 2.0 & 2.3 & 279.8 & 179.1 & 0.64 & 1.5 & 2.8 & 302.4 & 211.7 & 0.70 \\
\hline
\end{tabular}

Note:

In order to investigate the variation of results, variation analysis was done at each testing condition (curing time and test temperature):

- In $19 \mathrm{~mm}$ and $25 \mathrm{~mm}$ gradations, in all cases the coefficient of variation $(\mathrm{CV})$ were less than $15 \%$.

- In $37.5 \mathrm{~mm}$ gradation, in most cases the coefficient of variation $(\mathrm{CV})$ were less than $25 \%$.

2. Although some methods are mentioned that these two curing methods are the same, the obtained data shows vice versa.

3. The time and temperature of curing of the recycled mixes affect their characteristics. Although in the same samples, the amount of temperature-days in two curing methods are constant and the duration of curing in $40^{\circ} \mathrm{C}$ methods is more, it is concluded that the temperature is more important than the duration of curing. It is at the same results of Kavussi and Modarres (2010) research.

4. The results proved that by the same material, different mix design methods with different curing condition can lead to different recycled mixes with different characteristics. The same results have been reported by Martinez-Echevarria's et al. (2012) research.

\subsection{Investigation of the fatigue resistance of the prepared samples}

Stress-strain curve is plotted for each of the optimum mixes based on the mentioned methods. Many Studies show that, as the area under the curve is increased, the energy absorptivity is become more and the mix shows a better behavior against fatigue. The data is shown in Figure 1 and Table 5.

Table 5. The area under stress-strain curves in optimum samples in different curing methods $(\mathrm{kPa})$

\begin{tabular}{l|c|c|c}
\hline \multirow{2}{*}{ Curing method } & \multicolumn{3}{|c}{ Gradation } \\
\cline { 2 - 4 } & $19 \mathrm{~mm}$ & $25 \mathrm{~mm}$ & $37.5 \mathrm{~mm}$ \\
\cline { 2 - 4 } & The area under stress-strain curves $(\mathrm{kPa})$ \\
\hline 3 days at $40^{\circ} \mathrm{C}$ & 1.29 & 1.79 & 1.01 \\
2 days at $60^{\circ} \mathrm{C}$ & 1.80 & 2.92 & 1.21 \\
\hline
\end{tabular}

Based on Figure 1 and Table 5 the following results are obtained:

1. The recycled samples with 19,25 and $37.5 \mathrm{~mm}$ gradations have shown the greatest resistance to fatigue cracks, respectively. This order exists in the two studied curing methods.

2. The value of obtained area of the samples cured at $60{ }^{\circ} \mathrm{C}$ are greater than that of the samples cured at $40{ }^{\circ} \mathrm{C}$.

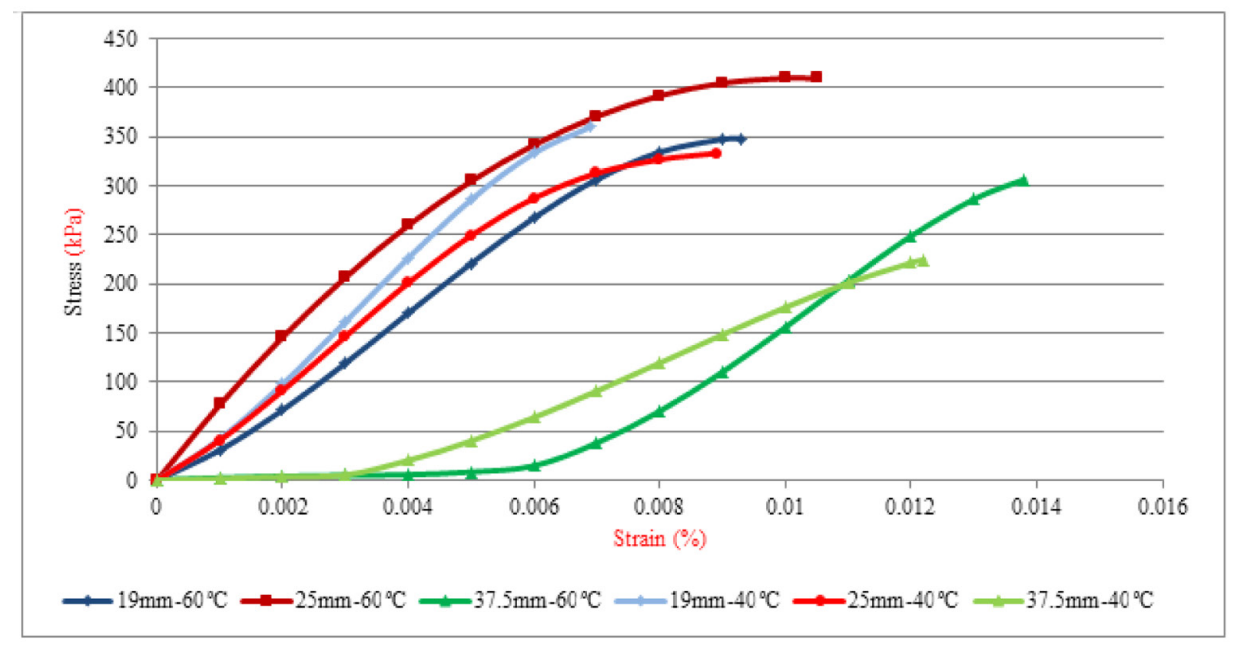

Fig. 1. Stress-strain curves for optimum samples at $40{ }^{\circ} \mathrm{C}$ and $60{ }^{\circ} \mathrm{C}$ curing 


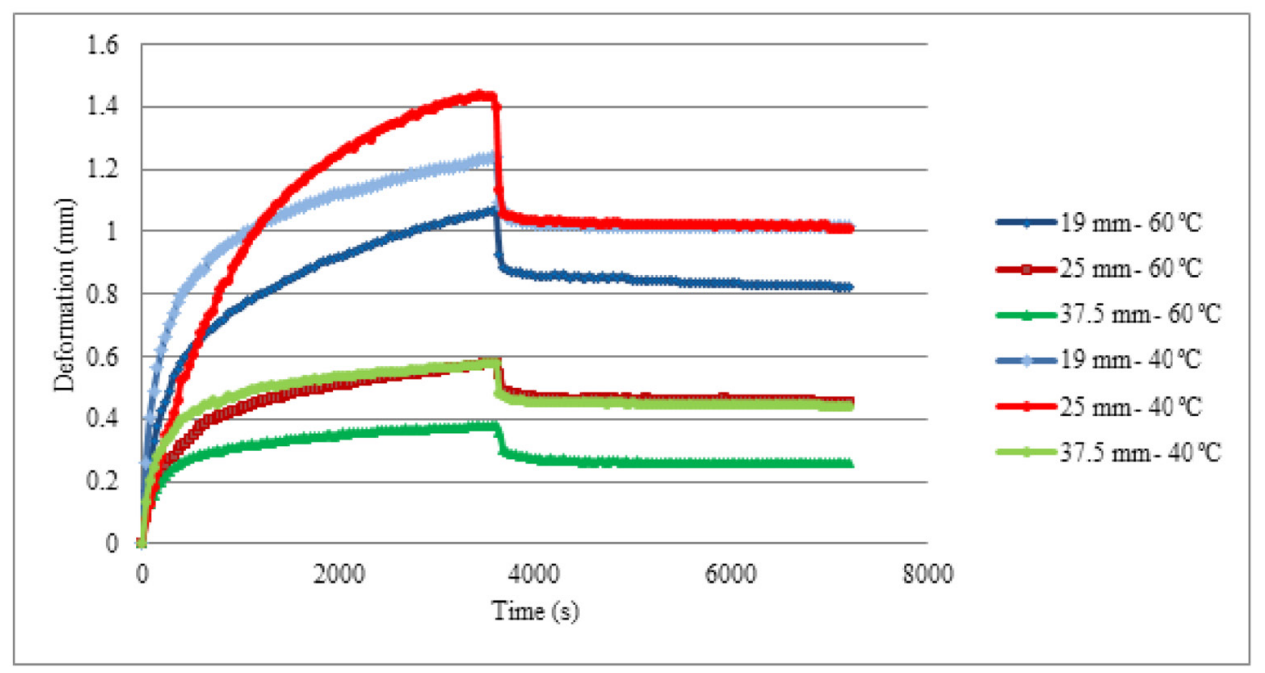

Fig. 2. Deformation of optimum mix samples under different curing methods $\left(40{ }^{\circ} \mathrm{C}\right.$ and $\left.60{ }^{\circ} \mathrm{C}\right)$

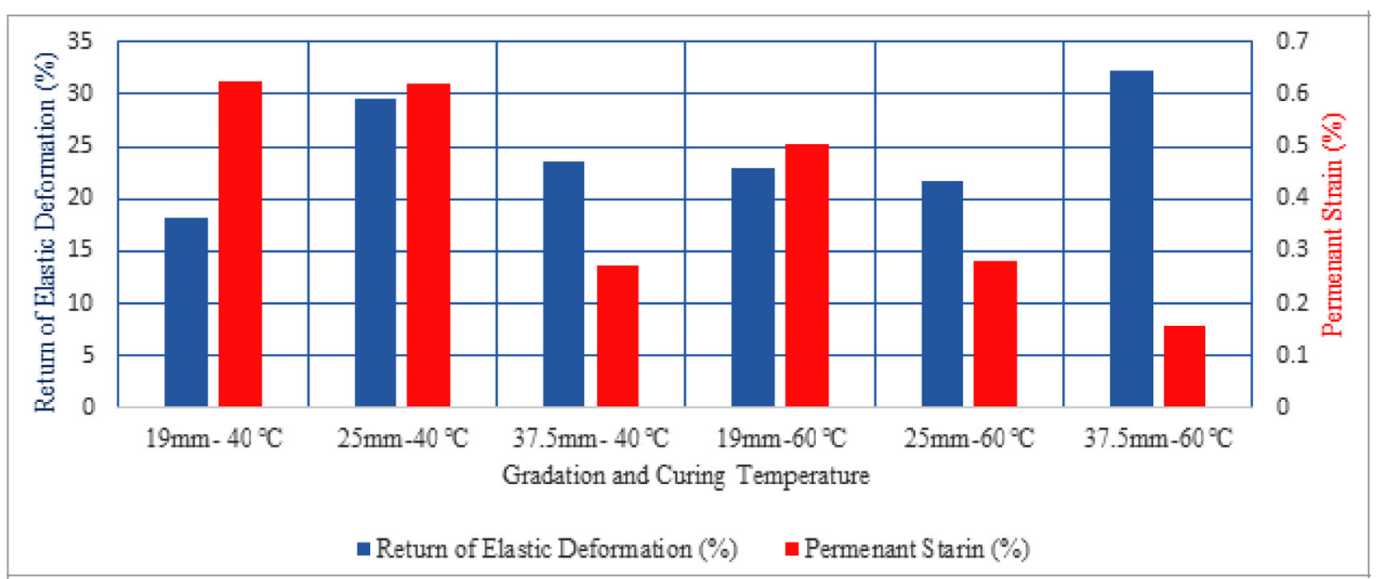

Fig. 3. Permanent strain and return of elastic deformation of recycled mix in static creep test

3. It is found that evaluation of the recycled mixes with $40{ }^{\circ} \mathrm{C}$ curing method does not reflect the final behavioral potential of these mixes. Therefore, it seems that the use of the results of $40{ }^{\circ} \mathrm{C}$ curing method caused underestimation of the recycled mixes properties and improper design of these mixes.

\subsection{Rutting resistance evaluation of the samples}

According to the results of the static creep test, the amount and time trend of deformation, permanent strain and the return rate of deformation for optimum design mixes were collected and evaluated. The results of static creep test are shown in Figure 2 and Figure 3.

Through the Figure 2, it is determined that in all types of recycled mixes, the return rate of deformation will continue until the end of the test process and complete return of deformation could not occur within 2 hours. This Figure show that the return of deformation of cured samples at $60{ }^{\circ} \mathrm{C}$ is greater than at $40{ }^{\circ} \mathrm{C}$. This can be due to incomplete samples curing at $40{ }^{\circ} \mathrm{C}$, the existence of more moisture and more ductility of these samples.
According to Figure 3 , in $40{ }^{\circ} \mathrm{C}$ curing method, although rutting resistance of $37.5 \mathrm{~mm}$ gradation is greater than $19 \mathrm{~mm}$ and $25 \mathrm{~mm}$ gradations, there is no difference between rutting behavior of 19 and $25 \mathrm{~mm}$ gradations. In $60{ }^{\circ} \mathrm{C}$ curing method, it concluded that the rutting resistance of the samples is affected by the maximum size of aggregates that is compatible with the theoretical method. Although the $37.5 \mathrm{~mm}$ gradation is not the optimum mix and has more air voids rather than other samples with smaller maximum aggregate size, it has more rutting strength than others. So it can be expected that it could show better behavior if it is well designed.

\section{Conclusions}

This study was designed to evaluate different design methods of cold recycled mixes to suggest a simple design method. The following conclusion can be drawn from the results:

- There is no consensus in the curing of recycled Mixes and most of them are following its own process. 
- The use 6-inch molds is suggested when the real aggregate size of RAP materials in the field is larger than $25 \mathrm{~mm}$.

- Because of the high prosity of recycled mixes, the results of specific gravity test based on the AASHTO T166 (2016) is not accurate so the use of AASHTO T331 (2013) is recommended.

- In authors suggesting method, as a simple, cheap and comprehensive test method, the ITS test is recommended to determine the optimum mix design.

- Despite of some theories that equate the two types of curing of cold recycled mixes $\left(3\right.$ days at $40{ }^{\circ} \mathrm{C}$ and 2 days at $60{ }^{\circ} \mathrm{C}$ ), those are not the same.

- Time and temperature of curing of recycled mixes affect their characteristics. Since in the same samples that cured with two types of studied curing methods the temperature-day is constant and curing time at $40{ }^{\circ} \mathrm{C}$ is higher than $60{ }^{\circ} \mathrm{C}$ therefore curing temperature has a greater role rather than time of curing.

- According to the ITS and TSR's results in different gradation, it concluded that the use of curing method of 3 days at $40{ }^{\circ} \mathrm{C}$ in mix design is not appropriate and it cannot show real and long-term behavior of recycled mixes so it can cause improper design of these mixes.

- The ITS's test results show that the selecting of optimum mix is dependent on curing conditions and different types of curing cause different optimum mixes.

- The moisture susceptibility test results show that by increasing the maximum aggregate size of the mixes the moisture susceptibility get worse.

- The rutting test results show that increasing the maximum aggregate size of the mixes improve the rutting resistance of the recycled mixes. Another important finding of this test is that despite of existence of high amount of air voids (above 14\%) in the $37.5 \mathrm{~mm}$ gradation it has a great rutting resistance.

\section{References}

AASHTO T166 Bulk specific gravity of compacted asphalt mixtures using saturated surface-dry specimens. American Association of State Highway and Transportation Officials, 2016.

AASHTO T283 Standard method of test for resistance of compacted asphalt mixtures to moisture-induced damage. American Association of State Highway and Transportation Officials, 2014.

AASHTO T331 Standard method of test for bulk specific gravity (Gmb) and density of compacted hot mix asphalt (HMA) using automatic vacuum sealing method. American Association of State Highway and Transportation Officials, 2013.

American Association of State Highway and Transportation Officials (AASHTO). 1998. Report on cold recycling of asphalt pavements. AASHTO-AGC-ARTBA Joint Committee Task Force 38 Report. American Association of State Highway and Transportation Officials, Washington, USA.
Apeagyei, A. K.; Diefenderfer, B. K. 2013. Evaluation of cold in-place and cold central-plant recycling methods using laboratory testing of field-cored specimens, Journal of Materials in Civil Engineering 25(11): 1712-1720. https://doi.org/10.1061/(ASCE)MT.1943-5533.0000717

Asphalt Recycling and Reclaiming Association. 2001. Basic asphalt recycling manual. Annapolis, USA.

Asphalt Recycling and Reclaiming Association. 2004. Basic asphalt recycling manual. Annapolis, USA.

ASTM C136 / C136M Standard test method for sieve analysis of fine and coarse aggregates. ASTM International, West Conshohocken, PA, 2014.

ASTM D244 Standard test methods and practices for emulsified asphalts. ASTM International, West Conshohocken, PA, 2009.

ASTM D6307 Standard test method for asphalt content of asphalt mixture by ignition method. ASTM International, West Conshohocken, PA, 2016.

ASTM D75 / D75M Standard practice for sampling aggregates. ASTM International, West Conshohocken, PA, 2014.

Bessa, I. S.; Almeida, L. R.; Vasconcelos, K. L.; Bernucci, L. B. 2016. Design of cold recycled mixes with asphalt emulsion and portland cement, Canadian Journal of Civil Engineering 43: 773-782. https://doi.org/10.1139/cjce-2016-0111

Bessa, I. S.; Aranha, A. L.; Vasconcelos, K. L.; Bernucci, L. L. B.; Silva, A. H. M.; Chaves, J. M. 2014. Caracterizacao mecanica de misturas asfalticas recicladas a frio, in $21^{\circ}$ Encontro de Asfalto- Instituto Brasileiro de Petróleo e Gás, 12-14 de maio de 2014, Rio de Janeiro, Brasileiro (in Portuguese).

Bocci, M.; Grilli, A.; Cardone, F.; Ferrotti, G. 2014. Full-depth reclamation for the rehabilitation of local roads: a case study, International Journal of Pavement Engineering 15(3): 191-201. https://doi.org/10.1080/10298436.2012.657196

Bou Jove, M.; Perez Jimenez, F. E.; De Bock, L. P.; Vanelstraete, A. 2004. Enhanced recycling techniques for asphalt pavements, as studied in the PARAMIX project, in International RILEM Conference on the Use of Recycled Materials in Building and Structures, 8-11 November 2004, Barcelona, Spain.

California Department of Transportation. 2005. Method of test for determining the percent of emulsified recycling agent to use for cold recycling of asphalt concrete. Lab Procedure No. 8.

Christensen, D.; Bonaquist, R. 2002. Mixture evaluation using gyratory specimens: Field shear test and IDT strength, in Annual Meeting of the Association of Asphalt Paving Technologists, 19 March 2002, Colorado Springs, USA.

Cox, B. C.; Howard, I. L. 2013. Cold in-place recycling and full-depth reclamation literature review. White Paper Number CMRC WP-13-1. Construction Materials Research Center, Mississippi State University, Starkville.

Cox, B. C.; Howard, I. L. 2015. Cold in-place recycling characterization framework and design guidance for single or multiple component binder systems. A report commissioned by Mississippi Department of Transportation (MDOT). Mississippi State University, Starkville.

Cross, S. A. 1999. Experimental cold in-place recycling with hydrated lime, Transportation Research Record: Journal of the Transportation Research Board 1684: 186-193. https://doi.org/10.3141/1684-22

Cross, S.A. 2003. Determination of superpave gyratory compactor design compactive effort for cold in-place recycled mixtures, Transportation Research Record: Journal of the Transportation Research Board 1819: 152-160. https://doi.org/10.3141/1819b-19 
Cross, S. A.; Kearney, E. R.; Justus, H. G.; Chesner, W. H. 2010. Cold-in-place recycling in New York State. Report C-06-21, New York State Department of Transportation, Albany, NY.

Du, S. 2015. Performance characteristic of cold recycled mixture with asphalt emulsion and chemical additives, Journal of Advances in Materials Science and Engineering, 1-8. https://doi.org/10.1155/2015/271596

Dudley, S. W.; Majidzadeh, K.; Kaloush, K. 1987. The recycling of cold-mix, in-place asphalt for low-volume roads in Ohio, Transportation Research Record: Journal of the Transportation Research Board 1106: 163-172.

Fiser, J.; Varaus, M. 2004. Cold recycling of pavements in the Czech Republic, in International RILEM Conference on the Use of Recycled Materials in Building and Structures, 8-11 November 2004, Barcelona, Spain.

Frigio, F.; Pasquini, E.; Canestrari, F. 2015. Laboratory study to evaluate the influence of reclaimed asphalt content on performance of recycled porous asphalt, Journal of Testing and Evaluation 43(6): 1308-1322.

https://doi.org/10.1520/JTE20140024

Fu, P.; Jones, D.; Harvey, J. T.; Bukhari, S. A. 2009. Laboratory test methods for foamed asphalt mix resilient modulus, Journal of Road Materials and Pavement Design 10(1): 188-212. https://doi.org/10.1080/14680629.2009.9690187

Illinois Department of Transportation. 2012. Special provision for cold in-place recycling (CIR) with emulsified asphalt. Special Provision LR 400-5.

Iowa Department of Transportation. 2008. Mix design method for CIR with engineered emulsion. Matls IM 504 Appendix B.

Iwański, M.; Chomicz-Kowalska, A. 2016. Application of the famed bitumen and bitumen emulsion to the road base mixes in the deep cold recycling technology, The Baltic Journal of Road and Bridge Engineering 11(4): 291-301. https://doi.org/10.3846/bjrbe.2016.34

Kansas Department of Transportation. 2014. Mix design procedures for CIR (Cold in place recycling) material. Kansas Department of Transportation Construction Manual, Part $\mathrm{V}$, Section 5.3.4.

Kandhal, P. S.; Cooley, L. A. 2003. Accelerated laboratory rutting tests: Evaluation of the asphalt pavement analyzer. NCHRP Report 508. Transportation Research Board, National Research Council. Washington, D.C.

Kavussi, A.; Modarres, A. 2010. A model for resilient modulus determination of recycled mixes with bitumen emulsion and cement from ITS testing results, Construction and Building Materials 24: 2252-2259. https://doi.org/10.1016/j.conbuildmat.2010.04.031

Kim, Y. 2007. Development of new mix design for cold in-place recycling using foamed asphalt: $\mathrm{PhD}$ Dissertation. University of Iowa.

Kim, Y.; Wen, H. 2002. Fracture energy from indirect tension testing, Journal of the Association of Asphalt Paving Technologists 71: 779-793.

Kim, Y.; Im, S.; Lee, H. D. 2011. Impacts of curing time and moisture content on engineering properties of cold in-place recycling mixtures using foamed or emulsified asphalt, Journal of Materials in Civil Engineering 23(5): 542-553. https://doi.org/10.1061/(ASCE)MT.1943-5533.0000209

Koh, C.; Roque, R. 2010. Use of nonuniform stress-state tests to determine fracture energy of asphalt mixtures accurately, Transportation Research Record: Journal of the Transportation Research Board 2181: 55-66.

https://doi.org/10.3141/2181-07

Lane, B.; Kazmierowski, T. 2005. Short term performance of an innovative cold in-place recycling technology in Ontario, in Proceedings of the 2005 Annual Conference of the
Transportation Association of Canada, 18-21 September 2005, Calgary, Alberta.

Lee, H.; Kim, Y. 2010. Development of mix design process for cold in-place recycling using emulsion, Phase III. Final report of TR-578 project. Iowa Highway Research Board, Iowa.

Lee, K. W. 2003. New mix-design procedure of cold in-place recycling for pavement rehabilitation, in Proceedings of the 82nd Transportation Research Board Annual Meeting, 12-16 January 2003, Washington, DC, USA.

Lee, K. W.; Brayton, T. E.; Huston, M. 2002. Development of performance based mix-design for cold in-place recycling (CIR) of bituminous pavements based on fundamental properties. A report commissioned by Federal Highway Administration. University of Rhode Island, Kingston.

Ma, T.; Zhao, Y.; Huang, X.; Zhang, Y. 2016. Using RAP material in high modulus asphalt mixture, Journal of Testing and Evaluation 44(2): 781-787.

Marcandali da Silva, A. H.; Vasconcelos, K. L.; Aranha, A. L.; Bernucci, L. B., Chaves, J. M. 2013. Laboratory and field evaluation of cold in-place RAP recycling, in Proceedings of the 92nd Transportation Research Board Annual Meeting, 13-17 January 2013, Washington, DC, USA.

Martinez-Echevarria, M. J.; Recasens, R. M.; Gamez, M. D. R.; Ondina, A. M. 2012. In-laboratory compaction procedure for cold recycled mixes with bituminous emulsions, Construction and Building Materials 36: 918-924. https://doi.org/10.1016/j.conbuildmat.2012.06.040

Miro, R.; Martinez, A.; Cancela, A. 2004. Case study of inplace recycled asphalt pavement of the N-536 highway in Spain, in Proceedings of the Transportation Research Board 83th annual meeting, 11-15 January 2004, Washington DC, USA.

Miro, R.; Perez, F. E.; Jimenez, P.; Castillo S. 2000. Mixed recycling with emulsion and cement of asphalt pavements. design procedure and improvements achieved, Journal of Materials and Structures 33: 324-330.

Montana Department of Transportation. 2015. Cold in-place recycling (Partial depth) mixture design. Special Provision 405-2.

Niazi, Y.; Jalili, M. 2009. Effect of Portland cement and lime additives on properties of cold in-place recycled mixtures with asphalt emulsion, Construction and Building Materials 23(3): 1338-1343. https://doi.org/10.1016/j.conbuildmat.2008.07.020

Roque, R.; Birgisson, B.; Drakos, C.; Dietrich, B. 2004. Development and field evaluation of energy-based criteria for top-down cracking performance of hot mix asphalt, Journal of the Association of Asphalt Paving Technologists 73: 229-260.

Sebaaly, P. E.; Bazi, G.; Hitti, E.; Weitzel, D.; Bemanian, S. 2004. Performance of cold in-place recycling in Nevada, Transportation Research Record: Journal of the Transportation Research Board 1896: 162-169. https://doi.org/10.3141/1896-16

Suleiman, N. 2002. A state-of-the-art review of cold in-place recycling of asphalt pavements in the Northern Plains region. University of North Dakota: School of Engineering and Mines.

Tebaldi, G.; Dave, E.; Marsac, P.; Muraya, P.; Hugener, M.; Pasetto, M.; Graziani, A.; Grilli, A.; Bocci, M.; Marradi, A.; Wendling, L.; Gaudefroy, V.; Jenkins, K.; Loizos, A.; Canestrari, F. 2014. Synthesis of standards and procedures for specimen preparation and in-field evaluation of coldrecycled asphalt mixtures, Road Materials and Pavement Design 15(2): 272-299.

https://doi.org/10.1080/14680629.2013.866707 
Texas Department of Transportation. 2004. Cold in-place recycling of asphalt concrete pavement. Special Specification 3254 .

Transportation Research Board. 2004. Top-down fatigue cracking of hot-mix asphalt layers: Models for initiation and propagation. A report commissioned by American Association of State Highway and Transportation Officials and performed under NCHRP Project 1-42. University of Florida.

Virginia Department of Transportation. 2014. Special provision for cold in-place recycling (CIR). Special Provision S315X01-1214.

Vislavičius, K.; Sivilevičius, H. 2013. Effect of reclaimed asphalt pavement gradation variation on the homogeneity of recycled hot-mix asphalt, Archives of Civil and Mechanical Engineering 13(3): 345-353.

https://doi.org/10.1016/j.acme.2013.03.003
Wegman D. E.; Sabouri M. R. 2016. Optimizing cold in-place recycling (CIR) applications through fracture energy performance testing. Research project Final report. Minnesota Department of Transportation, Minnesota.

Wirtgen, 2006. Cold recycling manual. $2^{\text {nd }}$ ed. Wirtgen $\mathrm{GmbH}$.

Yan, J.; Ni, F.; Tao, Z.; Jia, J. 2009. Development of asphalt emulsion cold in-place recycling specifications, in GeoHunan International Conference 2009. https://doi.org/10.1061/41042(349)7

Zhang, Z.; Roque, R.; Birgisson, B.; Sangpetngam, B. 2001. Identification and verification of a suitable crack growth law, Journal of the Association of Asphalt Paving Technologists 70: 206-241.

Bahador BAZRAFSHAN MOGHADAM. He is a lecturer at the university of Torbat Heydarieh. He graduated in MSc from the Sharif University of Technology of Iran in road and transportation engineering. He is experted in pavement recycling, road safety and pavement management systems. His original research is about "the investigation of pavement recycling method in Iran".

Hamid FARHAD MOLLASHAHI. He is a lecturer at the university of Torbat Heydarieh. He got his MSc in road and transportation engineering from Ferdowsi university of Mashhad, Iran. Academically, his interest and research is about road safety and accident economy. His original research is about "the effect of car insurance on traffic safety". 